\title{
Theoretical and experimental analysis on environmental pollution with exhaust gases at the mechanical dislocation of rocks, located in a protected nature environment.
}

\author{
Marin Silviu Nan ${ }^{1}$, Daniel Cosmin Vitan ${ }^{1 *}$, Sorina Daniela Anotoiu ${ }^{1}$, and Cristian Aron ${ }^{1}$. \\ ${ }^{1}$ University of Petrosani, 20 University street, 332006, Petrosani, Romania.
}

\begin{abstract}
The paper approaches the theoretical and experimental analysis of the level of exhaust gas pollution in a protected nature environmental, located in the mountain area, for excavation a trench. Due to the legislative provisions prohibiting the use of explosives in the nature reservation or other protected nature environmental areas, the mechanized excavation solution remains the only viable option. Excavation the trench through the mechanized solution must be carried out, taking into account the maximum level of pollution with exhaust gases provided in the legislative norms. According to the geotechnical data, the rock composition to be excavated on the route will be of different hardness, which involves impactors of various powers to displace the rock, on the one hand, and on the other, different excavators and bulldozers for the handling the material resulted from excavation. The theoretical research required to solve the problem has several stages, of which we mention: choosing the correct mechanization solution for displacing the hard and very hard rock; determination of fuel consumption, and energy consumption, respectively, transformation of the energy consumed in the liquid fuel necessary for the tool driving engines, and which generate exhaust gases.
\end{abstract}

\section{General considerations}

Excavating a trench in the mountain area, with hard and very hard rock in to a protected natural environment area, such as national park and natural reservations, is an understandable scientific and technological challenge.

The norms of pollution with exhaust gases in the protected areas are strict and do not leave space for errors or fluctuations regarding the maximum allowed limit of exhaust pollution. This the exhaust pollution is considered temporary, until the end of the trench, but even in these conditions the need to use excavation machines with high specifications of exhaust pollution norms, can reach the maximum limit at a certain point.

\footnotetext{
* Corresponding author: vitan.daniel.cosmin@gmail.com
} 
In hard rock, impact excavators are the only easily applicable solution in displacing hard and very hard non-homogeneous materials, such as gneiss, para gneiss, mica slate, limestone, dolomite, siliceous sandstone, etc.[1]

\section{Establishing mechanization solution for the displacement procedure.}

In this case, displacement is done by the cutting part acting perpendicularly on the rock surface in the case of hard and very hard rock. The studies carried out on rock cutting with impactors of high impact force and low frequency leads to a lower specific energy consumption, compared to a high frequency, lower impact force impactor. Although there are both pneumatically and hydraulically driven impactors, the modern solutions are equipped with hydraulic impactors. Hydraulic impactors allow easier correlation of energy with the impact frequency, depending on the rock and the presentation model of the working front, which is an essential aspect in trench excavation in hard and very hard rock.[2]

Table 1 presents this classification and some representative characteristics with abbreviation are called: (ET) extra hard rocks, (FT) very hard rocks, (T) hard rocks, (ST) sufficiently hard rocks, (M) soft rocks and (FM) very soft rocks.

Table 1. Classification of the rock massif .

\begin{tabular}{|c|c|c|c|c|c|c|}
\hline $\begin{array}{c}\text { Nr. } \\
\text { Crt. }\end{array}$ & Parameters & Rock types & $\begin{array}{c}\text { Resistance } \\
\text { to } \\
\text { compression } \\
\text { daN/cm }\end{array}$ & $\begin{array}{c}\text { Hardness } \\
\text { coefficient } \\
\mathbf{f}\end{array}$ & $\begin{array}{c}\text { Degree of } \\
\text { compactness }\end{array}$ & $\begin{array}{c}\text { Index of } \\
\text { quality } \\
\text { to } \\
\text { fissuring }\end{array}$ \\
\hline $\mathbf{0}$ & $\mathbf{1}$ & $\mathbf{2}$ & $\mathbf{3}$ & $\mathbf{4}$ & $\mathbf{5}$ & $\mathbf{6}$ \\
\hline $\mathbf{1}$ & $(\mathrm{ET})$ & $\begin{array}{c}\text { Quartzite, } \\
\text { granite }\end{array}$ & $\geq 1400$ & $\geq 14$ & $>85$ & $>25$ \\
\hline $\mathbf{2}$ & $(\mathrm{FT})$ & $\begin{array}{c}\text { gneiss, para- } \\
\text { gneiss, mica } \\
\text { slates }\end{array}$ & $\geq 800$ & $\geq 8$ & $>80$ & $>20$ \\
\hline $\mathbf{3}$ & $(\mathrm{T})$ & $\begin{array}{c}\text { limestone, } \\
\text { dolomite, } \\
\text { siliceous } \\
\text { sandstone }\end{array}$ & $600 \ldots 800$ & $6 \ldots 8$ & $40 \ldots 80$ & $10 \ldots 20$ \\
\hline $\mathbf{4}$ & $(\mathrm{ST})$ & $\begin{array}{c}\text { Loamy } \\
\text { sandstone }\end{array}$ & $400 \ldots 600$ & $4 \ldots 6$ & $20 \ldots 40$ & $1 \ldots 10$ \\
\hline $\mathbf{5}$ & $(\mathrm{M})$ & $\begin{array}{c}\text { Feldspar slate } \\
\mathbf{6}\end{array}$ & $200 \ldots 400$ & $2 \ldots 4$ & $10 \ldots 20$ & $0,05 \ldots 1$ \\
\hline & $(\mathrm{FM})$ & $\begin{array}{c}\text { Graphite } \\
\text { siliceous slate }\end{array}$ & $<100$ & $<1$ & $<10$ & $<0,05$ \\
\hline
\end{tabular}

By the analysis of the data presented in Table 1, one can say that in order to excavate the trench, excavation works are required with the help of impactor in rock of a (ET), (FT) and $(\mathrm{T})$ category and excavation works with the help of excavator buckets through (ST), (M) and (FM) category rock.

In Table 2 the tools recommended for the displacement work in optimum conditions are presented, for each type of operation in view of cutting the rock massif necessary to set up this construction. 
Table 2. Classification of tools for the displaced rock type

\begin{tabular}{|c|c|c|}
\hline $\begin{array}{c}\text { Nr. } \\
\text { Crt. }\end{array}$ & Operations carried out & Recommended tools \\
\hline $\mathbf{1}$ & $\begin{array}{c}\text { Displacement of(ET),(FT) and (T) rock with } \\
\text { impactor }\end{array}$ & $\begin{array}{c}\text { Excavator Komatsu PC 290 equipped with } \\
\text { BA 707 impactor }\end{array}$ \\
\hline $\mathbf{2}$ & Excavation of displaced material & $\begin{array}{c}\text { Komatsu PC 290* excavator and Komatsu PC } \\
228 \text { excavator }\end{array}$ \\
\hline $\mathbf{3}$ & (ST) and (M) rock excavation & $\begin{array}{c}\text { Komatsu PC 290* excavator and Komatsu PC } \\
228 \text { excavator }\end{array}$ \\
\hline $\mathbf{4}$ & $\begin{array}{c}\text { Material handling and (FM) rock } \\
\text { displacement }\end{array}$ & Caterpillar D6R LPG bulldozer \\
\hline
\end{tabular}

* For the use of Komatsu PC 290 excavator in the excavating operation, material displacement and (ST) and (M) rock excavation, demounting of the impactor and reequipping the excavator with direct or reversed bucket, as the case is, is necessary.

\section{Determination of the energy and fuel consumption.}

Combustion means a rapid exothermic oxidation process of combustible substances. A fuel is a body, a substance, which by specific reactions develops energy in the form of heat. Oxygen carrier means the substance that delivers the oxygen required for the combustion of the fuel. In the combustion process, the combustible substances react exothermichal the oxygen forming oxides. For the combustible to be considered combustible, it has to fulfil the conditions: the reaction speed should have a high value so that the developed energy would have practical utility; by reaction it should not produce damages to the ambient environment; the body, the substance should not have superior uses.[3,8]

\subsection{Classification:}

a) according to the nature of the reaction by which energy is released: -fossil fuels; nuclear fuels;

b) according to the state of aggregation: solid fuel; gaseous fuel; liquid fuel.

In Table 3 various energy powers of fuels are specified.

Table 3. Energy power for various fuels.

\begin{tabular}{|c|c|c|c|c|c|c|}
\hline \multirow{2}{*}{$\begin{array}{c}\text { Liquid fuel } \\
\text { Gasoline } \\
\end{array}$} & \multirow{2}{*}{$\begin{array}{c}\begin{array}{c}\text { Density at } \\
\mathbf{1 5}^{0} \mathbf{C} \\
{\left[\mathbf{k g} / \mathbf{m}^{3}\right]}\end{array} \\
760 \\
\end{array}$} & \multicolumn{4}{|c|}{ Mass participation \% } & \multirow{2}{*}{$\begin{array}{c}\begin{array}{c}\text { Energy } \\
\text { power } \mathbf{Q}_{\mathbf{i}} \\
{[\mathbf{k J} / \mathbf{k g}]}\end{array} \\
42035,0 \\
\end{array}$} \\
\hline & & 80,7 & 14,2 & 5,1 & - & \\
\hline Liquefied gases & 2220 & 82,5 & 17,5 & - & - & 46055,0 \\
\hline Diesel fuel & 870 & 86,6 & 12,9 & 0,2 & 0,3 & 41843,0 \\
\hline Petrol (gas) & 810 & 85 & 15 & - & - & 39775 \\
\hline $\begin{array}{c}\text { Gassy } \\
\text { combustible }\end{array}$ & $\begin{array}{l}\text { Chemical } \\
\text { formula }\end{array}$ & Mol & & $\begin{array}{l}\text { Dens } \\
{\left[\frac{\mathrm{k}}{\mathrm{m}}\right.}\end{array}$ & & $\left.\frac{\mathrm{kJ}}{\mathrm{m}_{\mathrm{N}}^{3}}\right]$ \\
\hline
\end{tabular}




\begin{tabular}{|c|c|c|c|c|}
\hline Acetylene & $\mathrm{C}_{2} \mathrm{H}_{2}$ & 26,00 & 1,710 & 56940,0 \\
\hline Hydrogen & $\mathrm{H}_{2}$ & 2,016 & 0,089 & 10760,0 \\
\hline Methane & $\mathrm{CH}_{4}$ & 16,00 & 0,716 & 35797,0 \\
\hline Ethane & $\mathrm{C}_{2} \mathrm{H}_{6}$ & 30,05 & 1,356 & 64350,0 \\
\hline Propane & $\mathrm{C}_{3} \mathrm{H}_{8}$ & 44,09 & 1,960 & 93573,0 \\
\hline Butane & $\mathrm{C}_{4} \mathrm{H}_{10}$ & 58,12 & 2,590 & 123552,0 \\
\hline Pentane & $\mathrm{C}_{5} \mathrm{H}_{12}$ & 72,140 & 3,220 & 137143,0 \\
\hline
\end{tabular}

\subsection{Combustion equation:}

In the case of a solid or liquid fuel, the quantity of water resulted from the combustion of hydrogen, to which that corresponding to initial humidity is added is $9 \mathrm{~h}+\mathrm{w}$ ( $9 \mathrm{~h}$ because according to the combustion reaction $\mathrm{H}_{2}+1 / 2 \mathrm{O}_{2} \rightarrow \mathrm{H}_{2} 0$ the quantity of water is 9 times higher than that of hydrogen). For a vaporization heat, $\mathrm{r}=2508[\mathrm{~kJ} / \mathrm{kg}]$, it results:

$$
H_{s}=H_{i}+2508 \cdot(9 h+w)\left[\frac{k J}{k g}\right]
$$

Use where: h, w represent the mass participation of hydrogen, and humidity of the fuel, respectively.

Since in the usual technical installations the temperature of gas evacuation is relatively high $\left(90 \div 160^{\circ} \mathrm{C}\right)$, anyhow higher than the temperature of the acid condensation point, water is eliminated in the form of vapor, thus in the calculations the inferior energy power Hi intervenes.[4] Energy power depends on the percentage of elements of combustible compounds, being equal to the sum of products between energy powers and corresponding mass or volume participation.

For a solid or liquid fuel inferior energy power is as below:

$$
H_{i}=33900 \cdot c+120120\left(h-\frac{o}{8}\right)+9250 \cdot w\left[\frac{k J}{k g \cdot c o m b}\right]
$$

where $\mathrm{c}, \mathrm{h}, \mathrm{o}, \mathrm{s}, \mathrm{w}$ represent [\%] of each element, the available hydrogen quantity for combustion being $\left(\mathrm{h}-\frac{\mathrm{o}}{8}\right)$, the rest being related to the oxygen present in the fuel.

Function of the nature of the fuel, its power is expressed in: $\mathrm{kJ} / \mathrm{kg}$, for solid and gaseous fuels; $\mathrm{kJ} / \mathrm{m}_{\mathrm{N}}^{3}$, for gaseous fuels; $\mathrm{kJ} / \mathrm{kmol}$, for any fuel type, if the molar $\operatorname{mass}(\mathrm{M})$ is known. Energy power is experimentally determined for the solid and heavy liquid ones with calorimetric bomb, and for volatile and gaseous liquid ones with Junkers calorimeter.[5]

The composition of a fuel is expressed by its elementary and immediate (technical) analysis. Elementary analysis expresses mass participations of various chemical elements that enter the fuel composition:

$$
c \div h \div s \div o \div n \div w+a=1 \mathrm{~kg}
$$

In the formula (3) the symbols are: c - mass participation of carbon contained in one $\mathrm{kg}$ fuel; $\mathrm{h}$ - mass participation of hydrogen contained in one $\mathrm{kg}$ fuel; $\mathrm{s}$ - mass participation of sulphur contained in one $\mathrm{kg}$ fuel; o - mass participation of oxygen contained in one $\mathrm{kg}$ fuel; $\mathrm{n}$ - mass participation of nitrogen contained in one $\mathrm{kg}$ fuel; $\mathrm{w}$ - mass participation of water contained in one kg fuel; a - mass participation of mineral substances, which make up ash, contained in one $\mathrm{kg}$ fuel. 


$$
\begin{gathered}
C+\mathrm{O}_{2} \rightarrow \mathrm{CO}_{2}+\mathrm{H}_{C} ; H_{c}=406139 \frac{\mathrm{kJ}}{\mathrm{kmolC}}=3384492 \frac{\mathrm{kJ}}{\mathrm{kgC}} \\
\mathrm{H}_{\mathrm{H}_{2}}=281129 \frac{\mathrm{kJ}}{\mathrm{kmolH}_{2}}=1405645 \mathrm{~kJ} / \mathrm{kgH}_{2} \\
\mathrm{~S}_{2}+\mathrm{O}_{2} \rightarrow \mathrm{SO}_{2}+\mathrm{H}_{\mathrm{s}} ; \mathrm{H}_{\mathrm{s}}=276104 \frac{\mathrm{kJ}}{\mathrm{kmolS}}=8628 \mathrm{~kJ} / \mathrm{kgS}
\end{gathered}
$$

$\mathrm{H}_{\mathrm{H} 2}$ is noticed to be 4 times higher than $H_{C}$. By complete combustion of $\mathrm{c} \mathrm{kg}$ de $\mathrm{C}, \mathrm{h} \mathrm{kg} \mathrm{\textrm {H } _ { 2 }}$ and a s kg of $\mathrm{S}$ the following heat are obtained: $\mathrm{Q}_{\mathrm{c}}=\mathrm{c} \cdot \mathrm{H}_{\mathrm{c}}[\mathrm{k}] ; \mathrm{Q}_{\mathrm{h}}=\mathrm{h} \mathrm{H}_{\mathrm{H} 2}[\mathrm{~kJ}] ; \mathrm{Q}_{\mathrm{s}}=\mathrm{s} \cdot \mathrm{H}_{\mathrm{s}}$ $[\mathrm{kJ}]$.

Complete combustion: Is characterized by the fact that as a result of the process there are no combustible elements left: there is no fuel loss (in the ash pit or by entraining in the chimney) and from a chemical point of view carbon is completely oxidized according to the known reaction:

$$
C+O \_2 \rightarrow C O \_2+40153 \mathrm{~kJ} / \mathrm{kmol}
$$

The other combustible components (hydrogen and sulphur) do not burn unless completely according to the above mentioned reactions:

$$
\begin{aligned}
& \mathrm{H}_{2}+\frac{1}{2} \mathrm{O}_{2} \rightarrow\left(\mathrm{H}_{2} \mathrm{O}\right)_{V}+242224 \mathrm{kj} / \mathrm{kmol} \\
& \mathrm{S}+\mathrm{O}_{2} \rightarrow \mathrm{SO}_{2}+276104 \mathrm{kj} / \mathrm{kmol}
\end{aligned}
$$

Combustion equations: Three fuel components are capable of combustion: carbon, hydrogen and sulphur $\left(\mathrm{C}, \mathrm{H}_{2}, \mathrm{~S}\right)$. Knowing the molecular masses of carbon $\left(\mathrm{M}_{\mathrm{C}}=12\right.$ $\mathrm{kg} / \mathrm{kmol})$, hydrogen $\left(\mathrm{M}_{\mathrm{H} 2}=2 \mathrm{~kg} / \mathrm{kmol}\right)$ and sulphur $\left(\mathrm{M}_{\mathrm{S}}=32 \mathrm{~kg} / \mathrm{kmol}\right)$, one can write:

$$
c \div h \div s \div o \div n \div w+a=1 \mathrm{~kg}
$$

Hence it results that for $1 \mathrm{~kg}$ fuel the necessary oxygen for combustion depend on the mass participations of carbon $\mathrm{c}$, of hydrogen $\mathrm{h}$ and sulphur $\mathrm{s}$. The oxygen corresponding to stoichiometric combustion (given by chemical reactions) is called minimum necessary oxygen. For it calculation the rule of three is used:

For $1 \mathrm{kmol} \mathrm{C}=12 \mathrm{~kg} \mathrm{C}, 1 \mathrm{kmol} \mathrm{O}_{2}\left(\mathrm{C}+\mathrm{O}_{2} \rightarrow \mathrm{CO}_{2}\right)$ is necessary.

For c kg C/kg fuel $\alpha$ kmol $\mathrm{O}_{2}$ are necessary:

$$
\alpha=\frac{c}{12}\left[\mathrm{kmolO}_{2} / \mathrm{kg} \text { fuel }\right]
$$

For $1 \mathrm{kmol} \mathrm{H}_{2}=2 \mathrm{~kg} \mathrm{H}_{2}, 1 / 2 \mathrm{kmol} \mathrm{O}_{2} \mathrm{H}_{2}+\frac{1}{2} \mathrm{O}_{2} \rightarrow \mathrm{H}_{2} \mathrm{O}$ is necessary.

For h $\mathrm{kg} \mathrm{H} / \mathrm{kg}$ fuel $\beta \mathrm{kmol} \mathrm{O}_{2}$ are necessary:

$$
\beta=\frac{h}{4}\left[\mathrm{kmolO}_{2} / \mathrm{kg} \text { fuel }\right]
$$

For $1 \mathrm{kmol} \mathrm{H}_{2}=2 \mathrm{~kg} \mathrm{H}_{2}, 1 / 2 \mathrm{kmol} \mathrm{O}_{2} \mathrm{H}_{2}+\frac{1}{2} \mathrm{O}_{2} \rightarrow \mathrm{H}_{2} \mathrm{O}$ is necessary.

For h $\mathrm{kg} \mathrm{H}_{2} / \mathrm{kg}$ fuel $\gamma \mathrm{kmol} \mathrm{O}_{2}$ are necessary:

$$
\gamma=\frac{s}{12}\left[\mathrm{kmolO}_{2} / \mathrm{kg} \mathrm{fuel}\right]
$$

In the fuel there is an $\mathrm{O}_{2}$ quantity that can participate in the combustion (o $\mathrm{kg} \mathrm{O}_{2} / \mathrm{kg}$ fuel.). This quantity should not be delivered from the exterior, thus it will be subtracted 
from the sum of calculated quantities. In order to transform $\mathrm{kg}$ in $\mathrm{kmol}$, the known equation is used:

$$
\begin{gathered}
N=\frac{m}{M}=\frac{\text { mass }}{\text { molecular mass }}=\frac{\mathrm{kg}}{\frac{\mathrm{kg}}{\mathrm{kmol}}}=\mathrm{kmol} \\
\delta=\frac{o}{32}\left[\mathrm{kmolO}_{2} / \mathrm{kg} \mathrm{fuel}\right] \\
O_{\text {min }}=\alpha+\beta+\gamma-\delta \quad\left[\mathrm{kmolO}_{2} / \mathrm{kg} \mathrm{fuel}\right] \\
O_{\text {min }}=\frac{c}{12}+\frac{h}{4}+\frac{s}{32}-\frac{o}{32} \quad\left[\mathrm{kmolO}_{2} / \mathrm{kg} \mathrm{fuel}\right]
\end{gathered}
$$

Usually oxygen is taken from the air. This contains per volume $21 \% \mathrm{O}_{2}$ and $79 \% \mathrm{~N}_{2}$ (conventional composition). Since per volume participation of a mixture is identical to the molecular one, it may be considered:

$1 \mathrm{kmol}$ air contains $0,21 \mathrm{kmol} \mathrm{O}_{2} ; \mathrm{L}_{\min } \mathrm{kmol}$ air contains $\mathrm{O}_{\min }$

$$
L_{\min }=\frac{\mathrm{O}_{2}}{0.21}\left[\mathrm{kmolO}_{2} / \mathrm{kg} \text { fuel }\right]
$$

which represents minimum air necessary for complete combustion.

Practice proves that for the combustion of a fuel, the air quantity $\mathrm{L}_{\min }$ is not sufficient. This is so because in certain conditions, the access to the combustion granule is difficult, thus for the safety of a complete combustion, a higher quantity should be provided $\mathrm{L}>\mathrm{L}_{\text {min }}$. Surplus coefficient (or air "excess") is the ratio:

$$
\lambda=\frac{L}{L_{\min }}=\frac{o}{o_{\min }},(\text { where } \mathrm{O} \text { is the effectively delivered oxygen })
$$

For $\lambda>1$, the burnt gasses have an oxidant character. The usual values for the air excess are: for solid fuels $\lambda=1,1-1,4$; for liquid fuels $\lambda=1,05-1,3$ for gaseous fuels: $\lambda=$ $1,05-1,2$. In the chemical reactions, the quantity of oxygen $\mathrm{O}_{\min }$ will be consumed, which will additionally provide (surplus oxygen), being found in the combustion gasses.

Incomplete combustion; Complete combustion is ideal, since it develops the energetic effect to a maximum. However, combustion can never be complete (perfect) irrespective of what they do. There are two causes which lead to incomplete combustion:

Mechanically incomplete combustion - in which part of the fuel leaves the combustion area from different reasons (small granulation and drops in the ash pan, dust - entrained in the chimney by draught, agglutinating fuel (which dampens with temperature) and which encloses un-burnt particles et.

$$
C+\frac{1}{2} \rightarrow C O+123312[k J / k m o l]
$$

There is no totally incomplete combustion (that is all carbon to react at $\mathrm{CO}$ ). It is considered that a quota $\mathrm{x}$ of carbon $\mathrm{c}$ of the fuel(thus $\mathrm{xc}$ ) reacts at $\mathrm{CO}_{2}$ and the rest $(1-\mathrm{x}) \mathrm{c}$ reacts at $\mathrm{CO}$. The rest of the reactions stay unmodified from the reasons shown before. This $\mathrm{x}$ should be understood as being in the range of 0 and $1(0 \leq \mathrm{x} \leq 1)$. If $\mathrm{x}=1$, the combustion has a complete character, and for $\mathrm{x}=0$, and combustion is totally incomplete. The minimum oxygen necessary for incomplete combustion is calculated with the rule of three as well:

For $1 \mathrm{kmol} \mathrm{C}=12 \mathrm{~kg} \mathrm{C} 1 \mathrm{kmol} \mathrm{O}_{2}\left(\mathrm{C}+\mathrm{O}_{2} \rightarrow \mathrm{CO}_{2}\right)$ is necessary

For $\mathrm{xc} \mathrm{kg} \mathrm{C} / \mathrm{kg}$ fuel, $\alpha$ ' $\mathrm{kmol} \mathrm{O}_{2}$ are necessary 


$$
\alpha^{\prime}=x \cdot \frac{c}{12}\left[\mathrm{kmol} \mathrm{O \_} 2 / \mathrm{kg} \cdot \mathrm{comb}\right]
$$

For $1 \mathrm{kmol} \mathrm{C}=12 \mathrm{~kg} \mathrm{C}, \frac{1}{2} \mathrm{kmol} \mathrm{O}_{2}\left(\mathrm{C}+\frac{1}{2} \mathrm{O}_{2} \rightarrow \mathrm{CO}\right)$ are necessary

For $(1-\mathrm{x}) \mathrm{c} \mathrm{kg} \mathrm{C} / \mathrm{kg}$ fuel, $\alpha$ " $\mathrm{kmol} \mathrm{O}_{2}$ is necessary

$$
\alpha^{\prime \prime}=\frac{1-x}{2} \cdot \frac{c}{12}=(1-x) \frac{c}{24}\left[\mathrm{kmol} O_{2} / \mathrm{kg} . \mathrm{fuel}\right]
$$

In rest, the resulted gases and the necessary oxygen are the same as in the complete combustion, since incomplete combustion does only affect carbon conversion. In complete combustion $\beta=\frac{h}{4}, \gamma=\frac{s}{32}$.

Similarly, in case of incomplete combustion the existing oxygen quantity in the fuel $\left(\delta=\frac{o}{32}\right)$, necessary for incomplete combustion, also drops.[6]

Consequently, the minimum oxygen required for incomplete combustion is:

$$
O_{\text {min }}=\alpha^{\prime}+\alpha^{\prime \prime}+\beta+\gamma-\delta=x \frac{c}{12}+(1-x) \frac{c}{24}+\frac{h}{4}+\frac{s}{32}+\frac{o}{32}\left[k m o l ~ O_{2} / k g c o m b\right]
$$

Since the oxygen reported at the complete combustion $\mathrm{O}=\lambda \cdot \mathrm{O}_{\min }$ is delivered to the combustion, the difference will be found in the combustion gases:

$$
\left(O_{2}\right)_{f}=(\lambda-1) O_{\min }+\frac{c}{24}(1-x)[\text { kmolo_2 } / \mathrm{kg} . \mathrm{comb}]
$$

It is noticed that the resulted oxygen is higher than than for complete combustion $(\lambda-1) O_{\min }$. The second term is due to the fact that in incomplete combustion of the carbon, only $1 / 2 \mathrm{kmol} \mathrm{O}_{2}$ is used, out of the $1 \mathrm{kmol}$ delivered for complete combustion.

Other modifications in gas volume refer to carbon:

$$
\left\{\begin{array}{l}
\left(\mathrm{CO}_{2}\right)_{f}=x \frac{c}{12} \\
(C O)_{f}=(1-x) \frac{c}{12}
\end{array} \quad[\mathrm{kmol} / \mathrm{kg} \text { of fuel. }]\right.
$$

The other gas volumes are identical as for complete combustion:

$$
\begin{gathered}
\left(\mathrm{H}_{2} \mathrm{O}\right)_{f}=\frac{h}{2}+\frac{W}{18}[\mathrm{kmol} \mathrm{H} / \mathrm{kg} . \mathrm{fuel}] \\
\left(\mathrm{SO}_{2}\right)_{f}=\frac{s}{32} \quad\left[\mathrm{kmol} \mathrm{SO} \mathrm{O}_{2} / \mathrm{kg} . \mathrm{fuel}\right] \\
\left.\left(\mathrm{N}_{2}\right)_{f}=\frac{0.79}{0.21} \lambda \cdot O_{\text {min }}+\frac{n}{28} \mathrm{kmol} \mathrm{N \_} 2 / \mathrm{kg} . \mathrm{fuel}\right]
\end{gathered}
$$

The volume of dry gases (without $\mathrm{H}_{2} \mathrm{O}, \mathrm{SO}_{2}$ and $\frac{n}{28}$ ) is:

$$
\left.V_{g u}=\frac{c}{0.21 \cdot 12}\left[(\lambda-0.21) \cdot \sigma+0.21 \frac{3-x}{2}\right] \mathrm{kmol} / \mathrm{kg} . \mathrm{fuel}\right]
$$

\section{Model for determining the volume of exhaust gases over the entire length considered, from the point of view of the combustion process.}

Based on the analytical relations mentioned in the previous sections, a mathematical calculation model has been established, to determine the volume of combustion gases. The calculation model started from the element analysis of Diesel fuel: $c=0,8579 ; \mathrm{h}=0,1418$; 
$\mathrm{o}=0,0001 ; \mathrm{s}=0,0002 ; \mathrm{w}=0,000001 ; \mathrm{n}=0,000001$. Other values that enter the calculation model are: Diesel fuel density $830 \mathrm{~kg} / \mathrm{m}^{3}$; normal volume in normal state $22,41 \mathrm{~m}^{3} \mathrm{~N} / \mathrm{kmol}$.

Based on the comments on incomplete combustion it is considered that the quota of the carbon reacting to $\mathrm{CO} 2$ is $0,97 \bullet \mathrm{c}=0,8322$. With these values, taking into consideration the mathematical model as well as the volumes, the exhaust gases volumes at the displacement of very hard and hard rock have been determined in the trench set up, in the following variants per transoms and in the entire length, presented in Fig. 1 and Fig. 2.[6,7]

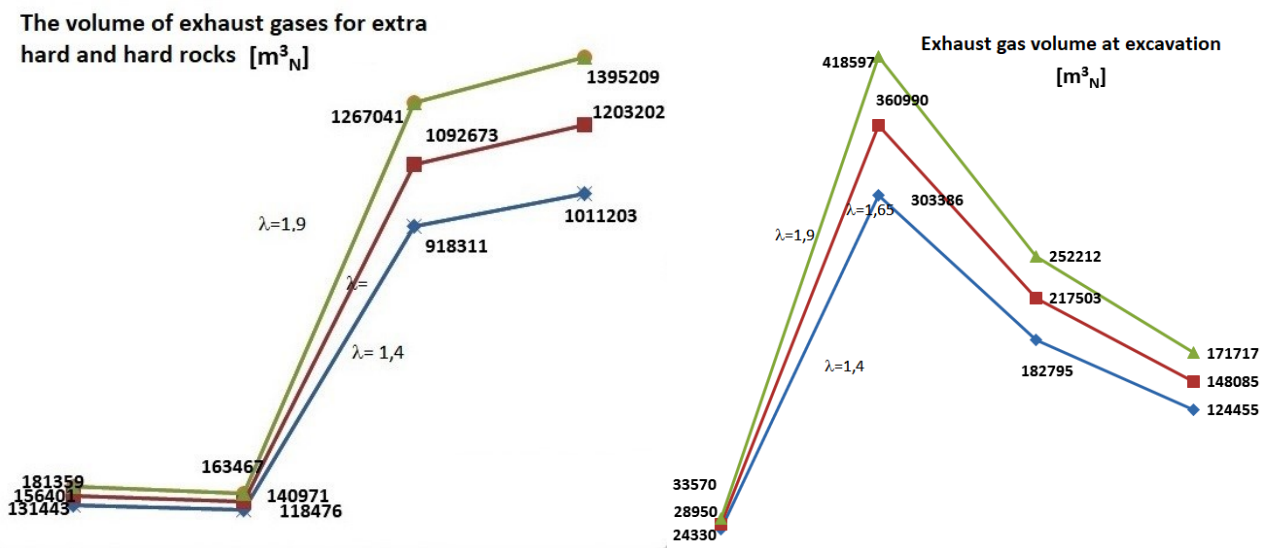

Fig. 1. Volume of exhaust gases for very hard and hard rock at the set up trench and set up passage.
Fig. 2. Volume of exhaust gases in the excavation of very hard and hard rock at the set up trench and set up passage.

where: blue line represent the excess air to the engine $(\lambda=1,4)$; red line represent the excess air to the engine $(\lambda=1,65)$; green line represent the excess air to the engine $(\lambda=1,9)$.

Road transport with internal combustion motor vehicles significantly contribute to pollution of surrounding atmosphere, affecting practically all ecosystems.

In Table 4 energy and fuel consumptions are centralized per operations and tool categories, having in mind the location, for very hard rock, excavated volume, energy consumption and fuel consumption for two types of mechanization solution. This centralizer is the result of the theoretical model expressed in the previous chapters.

Table 4. Consumption of energy and fuel in the displacement of very hard rock.

\begin{tabular}{|c|c|c|c|c|c|c|c|c|c|c|c|c|c|c|c|c|c|}
\hline \multirow[t]{2}{*}{ Location } & \multicolumn{2}{|c|}{ Total excavated rolume } & \multirow{2}{*}{\begin{tabular}{|c|}
$\begin{array}{c}\text { Total energy } \\
\text { consumption }\end{array}$ \\
$\mathrm{kWh}$
\end{tabular}} & \multirow{2}{*}{\begin{tabular}{|c|c}
$\begin{array}{c}\text { Diesel } \\
\text { consumptio } \\
1\end{array}$ \\
1
\end{tabular}} & \multirow{2}{*}{\begin{tabular}{|c|}
$\begin{array}{c}\text { Hourly } \\
\text { diesel } \\
\text { consumptio } \\
\text { II }\end{array}$ \\
1/h \\
\end{tabular}} & \multicolumn{2}{|c|}{$\begin{array}{c}\text { Mechanically ercarated } \\
\text { volume }\end{array}$} & \multirow{2}{*}{\begin{tabular}{|c}
$\begin{array}{c}\text { Total energy } \\
\text { consumption } \\
\text { during } \\
\text { escaration }\end{array}$ \\
kWh
\end{tabular}} & \multirow{2}{*}{$\begin{array}{c}\begin{array}{c}\text { Diesel } \\
\text { consumption } \\
\text { during } \\
\text { excaration }\end{array} \\
1\end{array}$} & \multirow{2}{*}{\begin{tabular}{|c|}
$\begin{array}{c}\text { Hourly } \\
\text { consumption } \\
\text { of diesel } \\
\text { during } \\
\text { excavation }\end{array}$ \\
$1 / \mathrm{h}$ \\
\end{tabular}} & \multirow{2}{*}{\begin{tabular}{|c|}
$\begin{array}{c}\text { Dislocated } \\
\text { volume } \\
\text { with the } \\
\text { impactor }\end{array}$ \\
$\mathrm{m}^{3}$ \\
\end{tabular}} & \multirow{2}{*}{\begin{tabular}{|c|c}
$\begin{array}{c}\text { Energy } \\
\text { consumption } \\
\text { at eracuation } \\
\text { displacement }\end{array}$ \\
$\mathrm{kWh}$ \\
\end{tabular}} & \multirow{2}{*}{ 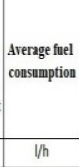 } & \multirow{2}{*}{\begin{tabular}{|c|}
$\begin{array}{c}\text { Volume } \\
\text { conveyed } \\
\text { with the } \\
\text { bulldozer }\end{array}$ \\
$\mathrm{m}^{3}$ \\
\end{tabular}} & \multirow{2}{*}{\begin{tabular}{|c|}
$\begin{array}{c}\text { Total } \\
\text { energy } \\
\text { consumption } \\
\text { of the } \\
\text { bulldozer }\end{array}$ \\
kWh \\
\end{tabular}} & \multirow{2}{*}{\begin{tabular}{|c}
$\begin{array}{c}\text { Diesel } \\
\text { consumptio } \\
\boldsymbol{n} \text { in } \\
\text { bulldozer }\end{array}$ \\
1 \\
\end{tabular}} & \multirow{2}{*}{$\begin{array}{c}\begin{array}{c}\text { Hourly } \\
\text { consumptio } \\
\text { n of diesel } \\
\text { bulldozer }\end{array} \\
1 / \mathrm{h}\end{array}$} \\
\hline & $\mathrm{m}^{3}$ & $t$ & & & & $\mathrm{~m}^{3}$ & $t$ & & & & & & & & & & \\
\hline L1 & 123,65 & 257,19 & 4258,52 & 437,12 & 17,72 & 44,6 & 75,82 & 283,04 & 29,05 & 19,62 & 79 & 3305,42 & 16,73 & 184,23 & 670,06 & 68,78 & 18,69 \\
\hline L3 & 171,55 & 356,82 & 5913,4 & 607 & 17,72 & 61,9 & 105,23 & 393,95 & 40,43 & 19,62 & 109,65 & 4588,82 & 16,73 & 255,6 & 930,71 & 25,53 & 18,69 \\
\hline 14 & 140,45 & 292,13 & 4906,57 & 503,65 & 17,72 & 48,76 & 82,89 & 309,79 & 31,79 & 19,62 & 91,69 & 3835,45 & 16,73 & 209,27 & 761,33 & 78,14 & 18,69 \\
\hline 15 & 132,9 & 276,43 & 4803,84 & 501,31 & 17,72 & 39,4 & 66,98 & 250,5 & 25,71 & 19,62 & 93,5 & 3912,06 & 16,73 & 198,02 & 721,28 & 74,03 & 18,69 \\
\hline L6 & 1079,7 & 2332,15 & 30268,77 & 3107,01 & 21,4 & 593,6 & 1009,12 & 8196,33 & 841,33 & 18,5 & 486,1 & 14208,16 & 22,73 & 1835,49 & 7864,28 & 807,25 & 22 \\
\hline 17 & 2473 & 5341,68 & 69663,44 & 7150,82 & 21,4 & 1340 & 2278 & 18505,33 & 1899,54 & 18,5 & 1133 & 33140,97 & 22,73 & 4204,1 & 18017,14 & 1849,42 & 22 \\
\hline 18 & 1859,5 & 4016,52 & 52380,32 & 5376,74 & 21,4 & 1007,6 & 1712,92 & 13914,45 & 1428,29 & 18,5 & 851,9 & 24918,73 & 22,73 & 3161,15 & 13547,14 & 1390,59 & 22 \\
\hline
\end{tabular}




\section{Pollution with real exhaust gases, of the excavation equipment, at the excavation site.}

Based on the performed calculations, the analytical model and the legislative determination, the measurement of the exhaust gases with a special device, was done at the site of the excavations. There are small oscillations that come from the dislocation of very strong rocks at the same time as maneuvering movements of the equipment, but which are random depending on the position where they dislocate. These random movements are given by the rugged terrain through which the trench must be dug, and the proper positioning of the machine is not accurate at first.

Fuel consumption is also influenced in these situations and the difference can be seen in the analysis of table 4 with table 5 , when comparing the same location.

Table 5. Consumption of energy and fuel in the displacement of very hard rock.

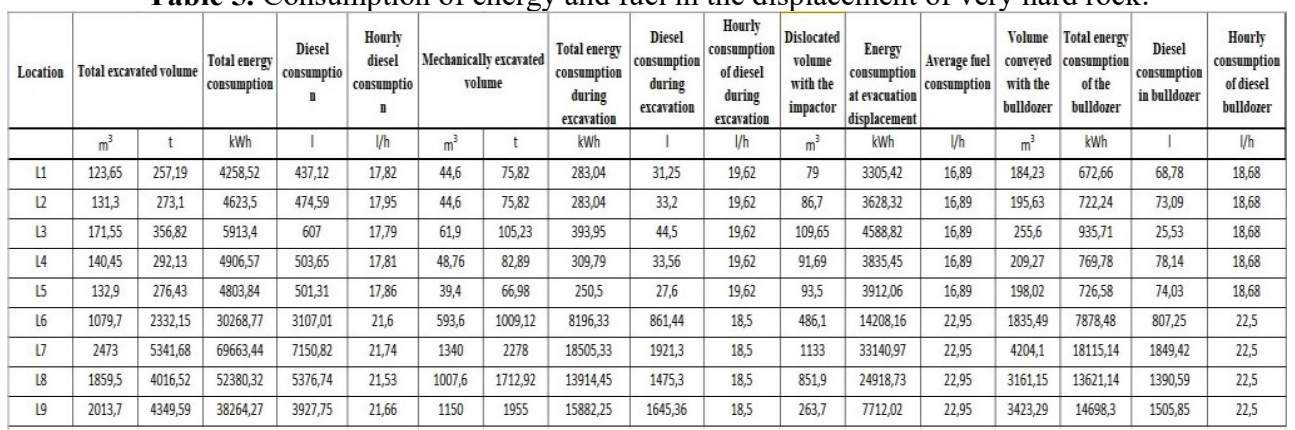

The analysis of the graphs from figure 1 and 2, of the theoretical exhaust gases, in comparison with figure 3 and 4, the real exhaust gases, demonstrates the good course and analytical model that was adopted for the theoretical determination of the exhaust gases.

Also from the analysis of the graphs from figures 1,2 and 3,4 it can be admitted that the imposed limit is not exceeded on the whole excavation route, even as combined and additional maneuvers when operating the equipment.

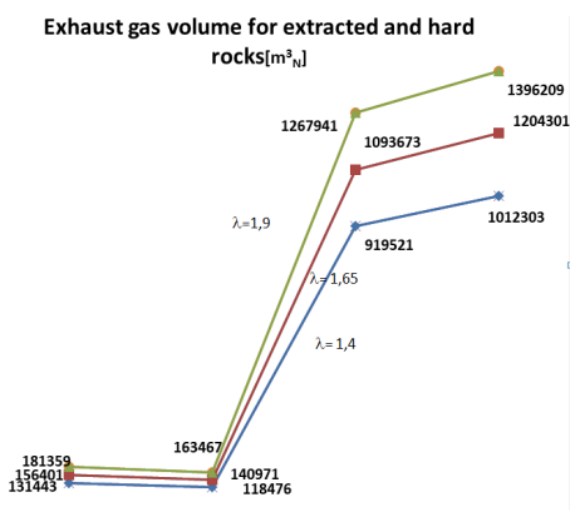

Fig. 3. Volume of exhaust gases for very hard and hard rock at the set up trench and set up passage, excavation site measurements.

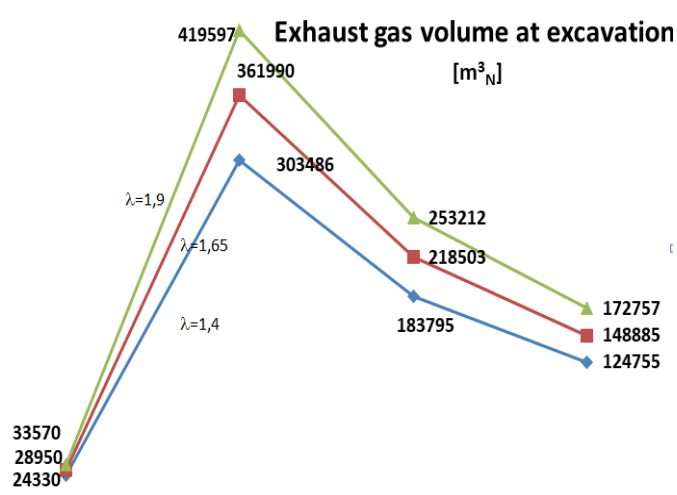

Fig. 4. Volume of exhaust gases in the excavation of very hard and hard rock at the set up trench and set up passage, excavation site measurements.

where: blue line represent the excess air to the engine $(\lambda=1,4)$; red line represent the excess air to the engine $(\lambda=1,65)$; green line represent the excess air to the engine $(\lambda=1,9)$. 


\section{Conclusions}

The research of the possibilities of carrying out an excavation in the form of a trench on a mountain routing with hard and very hard rock, situated in a protected area, such as an National Park or reservation, involved the development of the analytical model and measuring actual exhaust gases, describing the connection between nature of the rock, specific energy consumption, and energy consumption, respectively, fuel consumption and exhaust gasses volume, so that the conditions imposed by the legislation of the areas mentioned above would be met.

In this sense, in order to carry out this work in the area considered, exclusively by mechanic means, certain stages should be gone through, such as:

Establish quantitatively and qualitatively the parameters defining the displacement processes of non-homogeneous materials based on fundamental research developed along the years in the University of Petrosani.

Define the connections between various representative rock types along the routing, the displacement procedure and specific energy consumption with sufficiently credible probability to carryout quantitative aspects in the interaction process between the displacing machine and rock;

From technical-economic point of view for the work in the studied area, a series of factors are cumulated with restrictive senses determined by the category and declivity of the routing, the nature of the rock displaced, the pollution conditions for the execution of the work, climate, flora, fauna, etc.

The "dirty" greenhouse effect, determined by the microscopic particles that can reach the atmosphere, is manifested by the absorption of a relatively small quota of solar energy, diminishing the greenhouse effect itself.

The differences between the determined analytical model of the exhaust gases and the actual measured volume, demonstrate the fact that the oscillations of excess exhaust gases are due to a cumulation of operations adjacent to the basic operation.

The analysis of the exhaust gas volumes of both the model and the real one, is within the maximum norms accepted by the current legislation, they do not affect the fauna and flora, near the area through which the trench is excavated.

\section{References}

1. Al. Popescu. ,A.Todorescu - Mecanica rocilor in minerit, (Editura Universitas, Bucuresti, 1982).

2. I. Kovacs; N. Ilias; M.S. Nan - Regimul de lucru al combinelor miniere, (Editura Universitas, Petrosani 2000).

3. M.S Nan - Parametrii procesului de excavare la excavatoare cu rotor, (Editura Universitas, Petrosani, 2007).

4. I. Ilias, I. Kovacs si altii- Manualul inginerului de mine, vol. IV, (Editura Tehnica Bucuresti, 1988).

5. I. Ilias, I. Kovacs,M.S. Nan - Manualul inginerului de mine, vol. V, (Editura Tehnica Bucuresti, 1989).

6. G.Bacanu, G.Huminic-Termotehnica si masini termice, (Editura Transilvania, Brasov,2016).

7. M.S. Nan, D. Grecea,A.H. Nicola - Metodologia cercetarii stintifice, (Editura Universitas , Petrosani, 2016).

8. D.C. Petrilean - Termodinamica tehnica si masini termice, (Editura Agir, Bucuresti, 2010). 